\title{
HPLC METHOD VALIDATION AND APPLICATION FOR ORGANIC ACID ANALYSIS IN WINE AFTER SOLID-PHASE EXTRACTION
}

\author{
Krste Tašev $^{1,2}$, Marina Stefova ${ }^{2}$, Violeta Ivanova-Petropulos ${ }^{3 *}$ \\ ${ }^{1}$ State Phytosanitary Laboratory, Blvd. Alexander the Great bb, 1000 Skopje, Republic of Macedonia \\ ${ }^{2}$ Institute of Chemistry, Faculty of Natural Sciences and Mathematics, Ss. Cyril and Methodius University, \\ Arhimedova 5, Skopje, Republic of Macedonia \\ ${ }^{3}$ Faculty of Agriculture, Goce Delčev University, Krste Misirkov bb, Štip, Republic of Macedonia \\ violeta.ivanova@ugd.edu.mk
}

A solid-phase extraction method followed by reverse phase high-performance liquid chromatography (RP-HPLC) was optimized and validated for the quantitative determination of tartaric, malic, shikimic, lactic, citric and succinic acids in wine. Solid-phase extraction was carried out with C18 cartridges and extraction recoveries for all acids ranging from 98.3 to $103 \%$ were obtained. HPLC separation was performed with isocratic elution on a LiChrosorb RP-18 column $(250 \times 4.6 \mathrm{~mm} \mathrm{I.D.,} 5 \mu \mathrm{m})$ protected with the appropriate guard column. The mobile phase was a $5 \mathrm{mM}$ solution of $\mathrm{H}_{3} \mathrm{PO}_{4}$ with $\mathrm{pH} 2.1$ at a flow rate of $1 \mathrm{ml} / \mathrm{min}$. Detection of the organic acids was performed at $210 \mathrm{~nm}$. The developed method was validated by checking its linearity, limit of detection (LOD), limit of quantification (LOQ), precision and recovery. The method was applied to the analysis of organic acids in Macedonian red and white wines.

Keywords: wine; organic acids; separation; HPLC; validation

\section{ВАЛИДАЦИЈА И ПРИМЕНА НА НРЦС ЗА АНАЛИЗА НА ОРГАНСКИ КИСЕЛИНИ ВО ВИНО ПО ЦВРСТО-ФАЗНА ЕКСТРАКЦИЈА}

\begin{abstract}
Оптимизиран и валидиран е метод за квантитативна анализа на винска, јаболкова, шикимска, млечна, лимонска и килибарна киселина во вино со цврсто-фазна екстракција следена со реверзно-фазна високо ефикасна течна хроматографија (RP-HPLC). Цврсто-фазната екстракција е изведена со колони С18 и добиениот аналитички принос за сите киселини се движи од 98,3 до 103\%. Разделувањето со HPLC е извршено со изократско елуирање на LiChrosorb-ова колона RP$18(250 \times$ 4,6 mm I.D., $5 \mu \mathrm{m})$ користејќ́ соодветна претколона. Мобилната фаза којашто е употребена за елуирање е раствор од $\mathrm{H}_{3} \mathrm{PO}_{4}$ со концентрација $5 \mathrm{mM}$ и $\mathrm{pH} 2,1$ при проток од 1 $\mathrm{ml} / \mathrm{min}$. Детекцијата на органските киселини е извршена со следење на апсорбанцата на $210 \mathrm{~nm}$. Развиениот метод е валидиран со проверка на неговата линеарност, осетливост, граница на детекција (LOD), граница на квантификација (LOQ), аналитички принос и прецизност. Методот потоа е применет за анализа на органски киселини во македонски црвени и бели вина.
\end{abstract}

Клучни зборови: вино; органски киселини; сепарација; HPLC; валидација

\section{INTRODUCTION}

Organic acids are major components in wine that determine its acidity and influence its sensorial characteristics. Organic acids also influence the microbiological and biochemical stability of wine, particularly white wine [1]. At the lower $\mathrm{pH}$ values produced by organic acids, most bacteria do not 
grow, meaning wine is more stable and has greater potential for aging. During aging, acids are involved in reactions leading to the formation of esters and influence the development of the desired wine bouquet. In general, white wine has higher a)<smiles>O=C(O)C(O)C(O)C(=O)O</smiles>

(+)-Tartaric acid<smiles>O=C(O)CC(O)C(=O)O</smiles>

L(-)-Malic acid acidity than red wine. The organic acids in wine mainly originate from the grapes (tartaric, malic, citric and shikimic) (Fig. 1a) or they are formed during the alcoholic and malolactic fermentation (lactic, succinic and acetic) (Fig. 1b).<smiles>O=C(O)CC(O)(CC(=O)O)C(=O)O</smiles>

Citric acid<smiles>O=C(O)C1=C[C@@H](O)[C@H](O)[C@H](O)C1</smiles>

Shikimic acid b)<smiles>CC(O)C(=O)O</smiles><smiles>O=C(O)CCC(=O)O</smiles>

Succinic acid

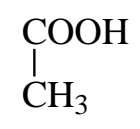

Acetic acid

Fig. 1. Chemical structures of organic acids in wine: a) originating from grapes and b) formed during vinification

Tartaric acid is one of the most abundant acids in grapes and wine with concentrations in unripe grapes as high as $15 \mathrm{~g} / \mathrm{l}$, while in the grape must, it ranges between 2 and $6 \mathrm{~g} / \mathrm{l}$ depending on the temperature to which the grapes were exposed [2]. Malic acid is also present in grapes and wine. Unripe grapes may contain as much as $25 \mathrm{~g} / \mathrm{l}$, but during ripening, its concentration is halved due to dilution as the grapes grow larger. The presence of malic acid results in a wine with "harsh" taste. During malolactic fermentation, malic acid converts to lactic acid, which leads to "wine softening" and fruity and vegetative aromas, as well as the mouthfeel of wine [3]. Shikimic acid is another grape organic acid present in low concentrations in the grape must $(0.01-0.15 \mathrm{~g} / \mathrm{l})$. It is considered a factor for the determination of grape origin $[4,5]$. Citric acid also belongs to the group of grape organic acids, and is an important component in biochemical and metabolic processes (e.g. Krebs cycle), which slow the yeast growth, but do not block it [2]. Its concentration in grape must ranges between 0.5 and $1 \mathrm{~g} / \mathrm{l}$. This component is allowed to be added to wine to regulate the acidity, but its level should not exceed $1 \mathrm{~g} / \mathrm{l}$. Succinic acid is a product of the alcoholic fermentation and gives a "bitter" note to the wine causing salivation. Acetic acid is formed during fermentation and it is the principal component of the volatile acidity of wine, which should be monitored throughout the winemaking process.

Among the different methods used for wine analysis, reversed phase high-performance liquid chromatography (RP-HPLC) is commonly employed for the separation of organic acids in wine and grapes using a C18 column and UV/Vis diodearray detector. Separation is usually performed with isocratic elution with an acidified polar solvent, such as an aqueous solution of phosphoric or sulfuric acid [6-9]. Organic acids show an absorbance maximum in the UV/Vis region at $210 \mathrm{~nm}$. Before HPLC analysis, sample pre-treatment procedures should be performed: (a) simple pretreatment, such as dilution and filtration, or more complex treatment, such as solid-phase extraction (SPE). The more common previous treatments are extraction with ion-exchange resins or with SPE cartridges and a derivatization procedure in order to avoid interference from sugars and colored compounds, which could co-elute with organic acids $[10,11]$.

In this work, a RP-HPLC method with diode array detection was developed and optimized for the determination of six organic acids of enological importance (tartaric, malic, shikimic, lactic, citric and succinic) in Macedonian red and white commercial 
wines. Sample pre-treatment included SPE of acids on $\mathrm{C} 18$ cartridges prior to the HPLC analysis.

\section{EXPERIMENTAL}

\subsection{Chemicals and reagents}

Standards of the organic acids used in this study are listed as follows: L(-) malic acid (>98\%), citric acid (>98\%) and succinic acid (>98\%), supplied from Sigma Aldrich (Steinheim, Germany), and $\mathrm{L}(+)$-tartaric acid $(>98 \%), \mathrm{L}(+)$-lactic acid $(>98 \%)$ and shikimic acid (>98\%), supplied from Fluka (Munich, Germany). $\mathrm{H}_{3} \mathrm{PO}_{4}(85 \%)$ was provided by Carlo Erba (Cornaredo, Italy). Water and acetonitrile of HPLC grade were from Sigma (Steinheim, Germany). The used HPLC columns were Supelco LiChrosorb RP-18 (250 x $4.6 \mathrm{~mm}$ I.D., $5 \mu \mathrm{m}$ particle size $)$, Varian C18 $(150 \times 4.6$ $\mathrm{mm}$ I.D., $5 \mu \mathrm{m}$ particle size), Agilent Zorbax C18 SB $(150 \times 4.6 \mathrm{~mm}$ I.D., $5 \mu \mathrm{m}$ particle size $)$ and Perkin Elmer C18 $(150 \times 4.6$ mm I.D., $5 \mu \mathrm{m}$ particle size). The cartridges used for SPE were Supelclean LC-18 (Supelco). PTFE filters $(25 \mathrm{~mm}$ $\times 0.45 \mu \mathrm{m})($ Supelco) were used for filtration of the samples.

\subsection{Wine samples}

Ten white (Riesling, Chardonnay, Temjanika, Smederevka and Traminec) and ten red (Vranec, Merlot and Cabernet Sauvignon) wines from different Vitis vinifera L. grape varieties from vintages 2011, 2012 and 2013 were collected directly from the commercial wineries located in different wine regions in Macedonia.

\subsection{Sample preparation using SPE}

SPE was performed in order to separate organic acids from the other components in the complex wine matrix, such as anthocyanins, carbohydrates and so on, which could co-elute with the acids and interfere in their measurement. For this purpose, the wine samples were first filtered and then subjected to SPE using Supelclean LC-18 SPE $500 \mathrm{mg}$ cartridges. The cartridges were conditioned with $1 \mathrm{ml}$ methanol and $1 \mathrm{ml}$ water. Then, the wine samples $(500 \mu \mathrm{l})$ were loaded on the cartridges. Elution was performed with two portions $(500 \mu \mathrm{l} \mathrm{each})$ of buffered water at $\mathrm{pH} 2.1$ with $\mathrm{H}_{3} \mathrm{PO}_{4}\left(5 \cdot 10^{-3} \mathrm{~mol} / \mathrm{l}\right)$. A volume of $10 \mu \mathrm{l}$ of the eluate was injected into the HPLC system for analysis of the organic acids.

\subsection{HPLC analysis}

A HPLC system (Varian Pro Star, Palo Alto, USA), equipped with an autosampler (model 410), photodiode array detector (PDA model 330), temperature control oven (model 500) and Varian Star Chromatography Workstation software (Ver. 6.41), was used for the identification and quantification of organic acids in the wine samples. Separation of the analytes was performed with isocratic elution on a Supelco LiChrosorb RP-18 column $(250 \mathrm{~mm}$ $\times 4 \mathrm{~mm}$ I.D., $5 \mu \mathrm{m}$ particle size). The mobile phase was an aqueous solution of $\mathrm{H}_{3} \mathrm{PO}_{4}$, with a concentration of $5 \cdot 10^{-3} \mathrm{~mol} / \mathrm{l}$ at $\mathrm{pH} 2.1$, containing $1 \%$ acetonitrile as an organic modifier, at a flow rate of $1 \mathrm{ml} / \mathrm{min}$. Separation and quantification of the organic acids was monitored at $210 \mathrm{~nm}$ and the sample injection volume was $10 \mu \mathrm{l}$.

\subsection{Method validation}

Linearity, precision, accuracy, limit of detection (LOD) and limit of quantification (LOQ) were investigated as method validation parameters. The compound peaks were identified by their retention times and compared with the standards and UV-Vis spectra. Quantification was performed with five point external calibration curves. Precision was determined as repeatability (six successive injections) and intermediate precision (three injections on five different days in one week). Accuracy was determined as a recovery for two different concentration levels. The LOD was determined as $\mathrm{LOD}=3 \times \mathrm{SD} /$ slope and the $\mathrm{LOQ}$ as $\mathrm{LOQ}=10 \times \mathrm{SD} /$ slope at the low concentration calibration level.

\subsection{Calibration curves}

For quantitative analysis of the organic acids in wine samples, external calibration curves were built in the following concentration ranges: tartaric acid $0.50-7.00 \mathrm{~g} / \mathrm{l}$; malic acid $0.05-2.50 \mathrm{~g} / \mathrm{l}$; lactic acid $0.05-1.50 \mathrm{~g} / 1$; citric acid $0.05-0.60 \mathrm{~g} / \mathrm{l}$; succinic acid $0.05-1.20 \mathrm{~g} / \mathrm{l}$ and shikimic acid $0.003-$ $0.07 \mathrm{~g} / \mathrm{l}$.

\subsection{Statistical analysis}

Statistical treatment, including calculation of the mean, standard deviation, relative standard deviation (RSD) and principal component analysis were performed using XLSTAT Software (Ver. 2012.6.09, Copyright Addinsoft 1995-2012). This was applied to the organic acid data set in order to 
represent patterns of similarities or differences between the studied wines in order to make a conclusion about possible classification.

\section{RESULTS AND DISCUSSION}

\subsection{Method optimization}

In order to develop a convenient, simple and accurate HPLC method for the quantitative determination of organic acids in wine, several investigations were performed. A set of HPLC columns with the same bonded phases (C18) were tested in our preliminary experiments, such as PerkinElmer Brownlee C18 (150 x 4.6 mm I.D., $5 \mu \mathrm{m}$ particle size), Varian Microsorb C18 $(250 \times 4.6 \mathrm{~mm}$ I.D., 5 $\mu \mathrm{m}$ particle size), Agilent Zorbax C18 SB (250 $\times$ $4.6 \mathrm{~mm}$ I.D., $5 \mu \mathrm{m}$ particle size) and Supelco LiChrosorb RP-18 $(250 \times 4.6 \mathrm{~mm}$ I.D., $5 \mu \mathrm{m}$ particle size). The general characteristics of the columns are presented in Table 1. Symmetrical peak shapes, satisfactory resolution between malic and shikimic acids and relatively short analysis times were obtained when separation was performed on the Supelco LiChrosorb RP-18 protected with the appropriate guard column (Fig. 2d).

When using the other three columns for separation, co-elution of malic and shikimic acids was observed, or the time of analysis was longer, as presented in Figure $2 \mathrm{a}, \mathrm{b}$ and c. This result can be explained by the higher carbon content of the Supelco LiChrosorb stationary phase, which is better deactivated, causing less retention and tailing due to sylanol groups on one side, and better resolution due to dispersive interactions on the other. The elution was monitored in the whole UV region and a wavelength of $210 \mathrm{~nm}$ was chosen for detection of organic acids because it gives the highest sensitivity.
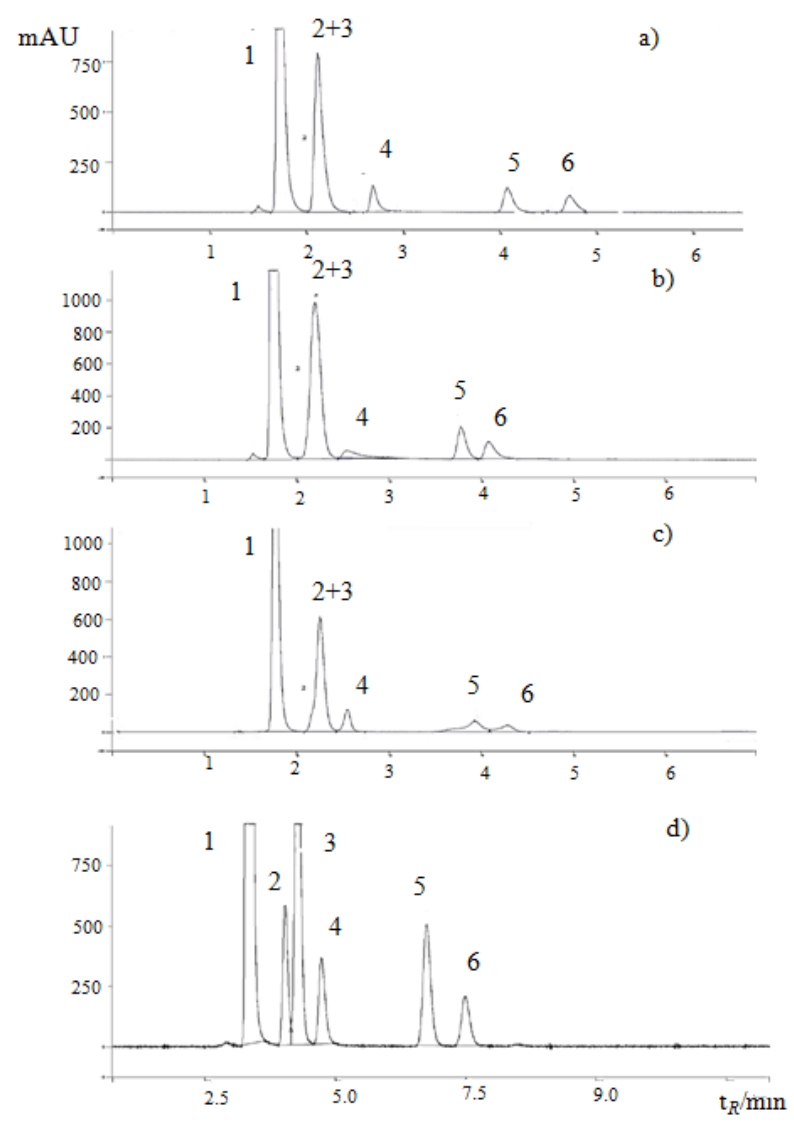

Fig. 2. UV-Vis chromatograms of standard solutions of organic acids obtained with the following columns: a) Perkin Elmer RP-18, b) Varian RP-18, c) Agilent ZORBAX C-18 SB and d) Supelco LiChrosorb RP-18. Peak numbers: 1 - tartaric acid; 2 malic acid; 3 - shikimic acid; 4 - lactic acid; 5 - citric acid and 6 - succinic acid.

Table 1

General characteristics of the HPLC columns used

\begin{tabular}{lccccccc}
\hline \hline Stationary phase & $\begin{array}{c}\text { Dimensions } \\
(\mathrm{mm})\end{array}$ & $\begin{array}{c}\text { Particle size } \\
(\mu \mathrm{m})\end{array}$ & $\begin{array}{c}\text { Pore size } \\
(\AA)\end{array}$ & $\begin{array}{c}\text { Content of } \\
\text { carbon, } \%\end{array}$ & Spherical & $\begin{array}{c}\text { High purity } \\
\text { silica gel }\end{array}$ & $\begin{array}{c}\mathrm{pH} \\
\text { range }\end{array}$ \\
\hline Agilent Zorbax C18 SB & $250 \times 4.6$ & 5 & 80 & 10 & yes & yes & $2-10$ \\
Varian Microsorb C18 & $250 \times 4.6$ & 5 & 100 & 12 & yes & yes & $2-10$ \\
PerkinElmer Brownlee C18 & $150 \times 4.6$ & 5 & 110 & 13 & yes & yes & $2-10$ \\
Supelco LiChrosorb RP-18 & $250 \times 4.6$ & 5 & 100 & 17 & no & no & $2-10$ \\
\hline \hline
\end{tabular}

The $\mathrm{pH}$ value of the mobile phase should be taken into consideration as a critical parameter for determination of organic acids in wine. This is due to the low $\mathrm{p} K_{\mathrm{a}}$ values of the organic acids: tartaric $\left(\mathrm{p} K_{\mathrm{a} 1}=3.03, \mathrm{p} K_{\mathrm{a} 2}=4.45\right)$, malic $\left(\mathrm{p} K_{\mathrm{a} 1}=3.40, \mathrm{p} K_{\mathrm{a} 2}\right.$ $=5.20)$, shikimic (no data available), lactic $\left(\mathrm{p} K_{\mathrm{a} 1}=\right.$
3.86), citric $\left(\mathrm{p} K_{\mathrm{a} 1}=3.09, \mathrm{p} K_{\mathrm{a} 2}=4.75, \mathrm{p} K_{\mathrm{a} 3}=5.41\right.$, $\left.\mathrm{p} K_{\mathrm{a} 4}=6.39,6.40\right)$ and succinic acid $\left(\mathrm{p} K_{\mathrm{a} 1}=4.2\right.$, $\left.\mathrm{p} K_{\mathrm{a} 2}=5.6\right)[2,10]$, meaning that at $\mathrm{pH}$ values above 4 or 5 , these organic acids are present in their anionic forms. Therefore, in our study, the effect of mobile phase $\mathrm{pH}$ (between $\mathrm{pH} 2$ and 10) 
was tested through the analyte retention and the shape of analyte peaks. When using a mobile phase with a $\mathrm{pH}$ higher than 6 , the separation was poor and the analysis time was relatively long (data not shown), which could be explained by the poor retention of the anionic forms on the reversed phase. When lowering the $\mathrm{pH}$ value of the mobile phase, the equilibrium was shifted towards the non-dissociated forms of the acids, separation improved and the best resolution between the peaks with short analysis time was obtained with a mobile phase with $\mathrm{pH}$ 2.1. Additionally, acetonitrile
(1\%) was added as a modifier in order to protect the column and prolong its life.

\subsection{Method validation}

The linearity data, including the slope, intercept and coefficient of determination, are presented in Table 2. As can be seen from the table, the linearity of the method, tested at five concentration calibration levels for each organic acid, is satisfactory in all cases with coefficients of determination $\left(R^{2}>0.99\right)$ ranging from 0.9988 for succinic acid to 0.9998 for tartaric acid.

T a b l e 2

Linear regression data: range of determination, coefficients of the regression curves (slope and intercept), coefficient of determination $R^{2}, L O D$ and $L O Q$

\begin{tabular}{lcrcccc}
\hline \hline Organic acids & Range $(\mathbf{g} / \mathbf{l})$ & Slope & Intercept & $\boldsymbol{R}^{\mathbf{2}}$ & LOD $(\mathbf{g} / \mathbf{L})$ & LOQ $(\mathbf{g} / \mathbf{l})$ \\
\hline Tartaric acid & $0.5-7.00$ & 1627 & 51969 & 0.9999 & 0.0028 & 0.0093 \\
Malic acid & $0.05-2.50$ & 817 & -3718 & 0.9999 & 0.0118 & 0.0389 \\
Shikimic acid & $0.003-0.07$ & 52240 & 70137 & 0.9999 & 0.0007 & 0.0026 \\
Lactic acid & $0.05-1.50$ & 669 & 1628 & 0.9999 & 0.0136 & 0.0449 \\
Citric acid & $0.05-0.60$ & 927 & 7421 & 0.9996 & 0.0128 & 0.0423 \\
Succinic acid & $0.05-1.20$ & 508 & -3109 & 0.9999 & 0.0123 & 0.0406 \\
\hline \hline
\end{tabular}

The order of acids is according to their elution in chromatographic separation (Fig. 2).

The LOD and LOQ were determined in the low concentration calibration region and ranged from 0.0007 to $0.0136 \mathrm{~g} / \mathrm{l}$ and from 0.0026 to $0.0448 \mathrm{~g} / \mathrm{l}$, respectively.

The accuracy of the procedure was checked using the standard addition method. One Vranec wine sample was spiked with the appropriate vol- umes of mixed standard solution of organic acids at two concentration levels (Table 3). Satisfactory results for the recovery at both concentration levels ranged from 95.7 to $105 \%$ and from 94.5 to $105 \%$, confirming that the method is accurate and convenient for quantitative analysis of organic acids in red wine.

Ta b l e 3

Standard additions for checking the accuracy of the SPE-RP-HPLC method for the determination of organic acids in wine samples $(n=3)$

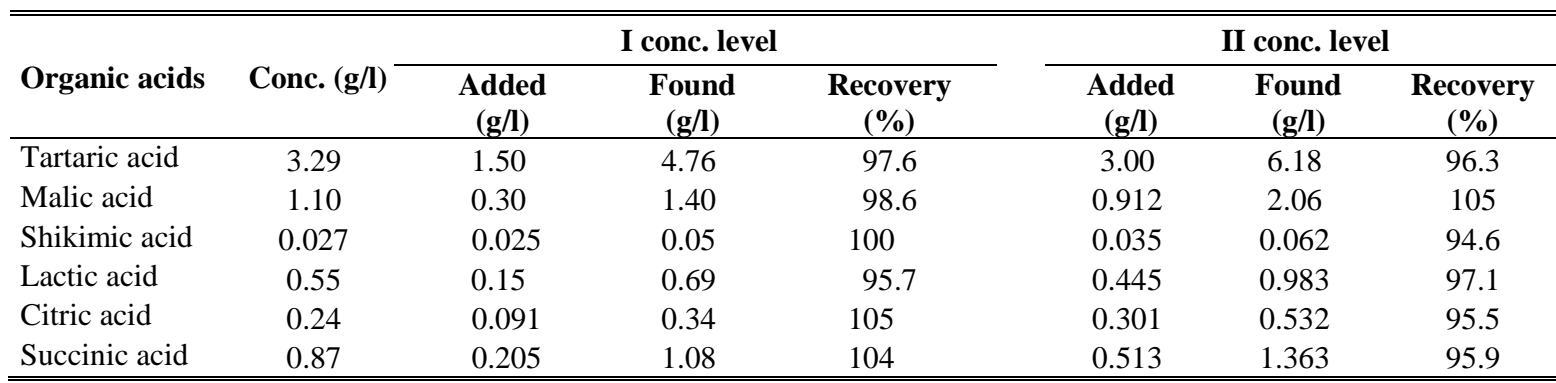

Additionally, to check the repeatability of the method, six replicate measurements on an actual red wine sample were performed within one day. The RSDs of the six replicate samples for each acid ranged from $1.03 \%$ for malic acid to $3.45 \%$ for lactic acid (Table 4). Reproducibility was also checked with replicate samples analyzed on five different days ( 3 replicates $\times 5 \mathrm{~d}$ ) and the RSD for each acid was calculated and it ranged from $2.89 \%$ for citric acid to $4.44 \%$ for lactic acid (Table 4). 
T a ble 4

Repeatability and reproducibility for each organic acid $(\mathrm{g} / \mathrm{l})$ in red wine

\begin{tabular}{ccccccc}
\hline \hline Red wine & Tartaric acid & Malic acid & Shikimic acid & Lactic acid & Citric acid & Succinic acid \\
\hline \multicolumn{7}{c}{ Repeatability (6 repetitions during one day) } \\
\hline$\langle x>$ & 3.29 & 1.10 & 0.028 & 0.55 & 0.24 & 0.87 \\
SD & 0.053 & 0.011 & 0.0004 & 0.019 & 0.0051 & 0.025 \\
$R S D(\%)$ & 1.61 & 1.03 & 1.69 & 3.45 & 2.10 & 2.89 \\
\hline & & \multicolumn{7}{c}{ Reproducibility (3 repetitions $\times 5$ days) } \\
\hline SD & 3.42 & 0.029 & 0.58 & 0.248 & 0.869 \\
$R S D(\%)$ & 0.136 & 0.045 & 0.001 & 0.025 & 0.0072 & 0.028 \\
\hline \hline
\end{tabular}

$\langle\mathrm{x}\rangle$ - average value, $\mathrm{SD}$ - standard deviation, $\mathrm{RSD}$ - relative standard deviation

\subsection{Application to wine sample analysis}

The optimized and validated method was applied to the analysis of organic acids in Macedonian white and red wines. Table 5 summarizes the concentrations of individual organic acids in white and red Macedonian wines determined by HPLC. The chromatogram presenting separation of organic acids at $210 \mathrm{~nm}$ in Vranec red wine is shown in Figure 3.

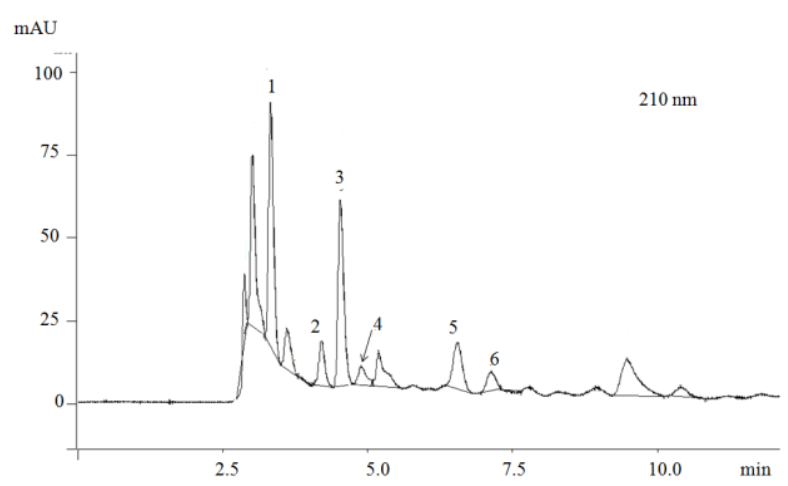

Fig. 3. UV-Vis chromatogram of organic acids in Vranec wine. Peak numbers: 1 - tartaric acid; 2 - malic acid; 3 - shikimic acid; 4 - lactic acid; 5 - citric acid and 6 - succinic acid.

In total, six acids were determined, including tartaric, malic, lactic, citric, succinic and shikimic acid. Tartaric acid was the dominant compound in all wines, both red and white. Its content in white wines ranged from $0.61 \mathrm{~g} / \mathrm{l}$ in Chardonnay wine to $2.22 \mathrm{~g} / \mathrm{l}$ in Temjanika. Red wines contained between 1.45 and $2.26 \mathrm{~g} / \mathrm{l}$ (Table 5). Tartaric acid, which influences the acidity of wines, was present in a highest amount in the red wine Cabernet Sauvignon $(2.26 \mathrm{~g} / \mathrm{l})$. In general, red wines contained slightly higher amounts of tartaric acid (on average $1.75 \mathrm{~g} / \mathrm{l}$ ) compared to white wines (on average $1.54 \mathrm{~g} / \mathrm{l})$.
Malic acid ranged between 0.12 and $0.83 \mathrm{~g} / \mathrm{l}$ for the white wines and up to $0.88 \mathrm{~g} / \mathrm{l}$ for the red wines (Table 5). In fact, the concentration of malic acid is highest at the beginning of alcoholic fermentation when the organic acids are extracted from the grapes. After fermentation, malic acid is converted into lactic acid, spontaneously, or in the presence of malolactic bacteria, during the malolactic fermentation $[2,12]$. As a consequence of this process, the content of malic acid decreases and the content of lactic acid increases in wine. In our study, white wines contained relatively high concentrations of malic acid and relatively low concentrations of lactic acid, meaning that malolactic fermentation was not completed in these samples. Alternatively, almost all red wines (except Vranec 4) presented low concentrations of malic acid, since it was almost completely converted into lactic acid as a result of the successful malolactic fermentation. Thus, the average content of lactic acid was $0.18 \mathrm{~g} / \mathrm{l}$ in the white wines and $0.51 \mathrm{~g} / \mathrm{l}$ in the red wines.

Citric acid was present in higher concentrations in the white wines (on average $0.25 \mathrm{~g} / \mathrm{l}$ ) compared to the red wines (on average $0.11 \mathrm{~g} / \mathrm{l}$ ) (Table 5). Usually, this acid is added to wine in order to correct the wine acidity and therefore its content should be controlled. All tested wines contained citric acid concentrations lower than $1 \mathrm{~g} / \mathrm{l}$, in accordance with regulations [13]. In addition, succinic acid, which is a by-product of yeast metabolism during fermentation, with a bitter-salty flavor, was found in low concentrations in both red and white wines (average value for white wines of $0.18 \mathrm{~g} / \mathrm{l}$ and average value for red wines of $0.33 \mathrm{~g} / \mathrm{l})$. Shikimic acid was present in lowest concentrations compared to the other acids, as expected, since this acid is also present in the lowest concentrations in grapes. Thus, the average value of this acid in red wines was higher $(0.0127 \mathrm{~g} / \mathrm{l})$ than in white wines $(0.0046 \mathrm{~g} / \mathrm{l})$, ranging from 0.009 to $0.026 \mathrm{~g} / \mathrm{l}$ and from 0.002 to $0.007 \mathrm{~g} / 1$, respectively (Table 5). 
Table 5

Organic acid contents in commercial red and white wines (in g/l)

\begin{tabular}{|c|c|c|c|c|c|c|c|c|}
\hline & Wine & Vintage & $\begin{array}{c}\text { Tartaric } \\
\text { acid }\end{array}$ & Malic acid & Lactic acid & Citric acid & Succinic acid & $\begin{array}{c}\text { Shikimic } \\
\text { acid }\end{array}$ \\
\hline & White wines & & & & & & & \\
\hline W1 & Riesling 1 & 2012 & $1.94 \pm 0.01$ & $0.34 \pm 0.01$ & $0.15 \pm 0.00$ & $1.59 \pm 0.01$ & $0.15 \pm 0.01$ & $0.004 \pm 0.00$ \\
\hline W2 & Chardonnay 1 & 2012 & $1.78 \pm 0.01$ & $0.44 \pm 0.01$ & $0.07 \pm 0.01$ & $1.24 \pm 0.01$ & $0.16 \pm 0.00$ & $0.007 \pm 0.00$ \\
\hline W3 & Temjanika & 2012 & $2.22 \pm 0.01$ & $0.36 \pm 0.00$ & $0.09 \pm 0.01$ & $1.67 \pm 0.01$ & $0.13 \pm 0.01$ & $0.002 \pm 0.00$ \\
\hline W4 & Smederevka 1 & 2012 & $1.04 \pm 0.00$ & $0.17 \pm 0.01$ & $0.30 \pm 0.01$ & $0.95 \pm 0.00$ & $0.31 \pm 0.00$ & $0.005 \pm 0.00$ \\
\hline W5 & Smederevka 2 & 2012 & $1.96 \pm 0.00$ & $0.12 \pm 0.00$ & $0.27 \pm 0.00$ & $0.87 \pm 0.01$ & $0.38 \pm 0.00$ & $0.005 \pm 0.00$ \\
\hline W6 & $\begin{array}{l}\text { Cuve (Riesling } \\
\text { and Smederevka) }\end{array}$ & 2012 & $1.60 \pm 0.01$ & $0.18 \pm 0.01$ & $0.27 \pm 0.01$ & $2.51 \pm 0.01$ & $0.20 \pm 0.00$ & $0.004 \pm 0.00$ \\
\hline W7 & Smederevka 3 & 2013 & $1.45 \pm 0.01$ & $0.52 \pm 0.01$ & $0.79 \pm 0.00$ & $3.05 \pm 0.01$ & $0.09 \pm 0.00$ & $0.006 \pm 0.00$ \\
\hline W8 & Riesling 2 & 2013 & $1.69 \pm 0.00$ & $0.67 \pm 0.01$ & $0.13 \pm 0.01$ & $3.31 \pm 0.00$ & $0.10 \pm 0.00$ & $0.002 \pm 0.00$ \\
\hline W9 & Traminec & 2013 & $1.09 \pm 0.01$ & $0.83 \pm 0.01$ & $0.15 \pm 0.01$ & $5.81 \pm 0.01$ & $0.19 \pm 0.01$ & $0.007 \pm 0.00$ \\
\hline \multirow[t]{3}{*}{ W10 } & Chardonnay 2 & 2013 & $0.61 \pm 0.00$ & $0.73 \pm 0.01$ & $0.23 \pm 0.01$ & $3.73 \pm 0.01$ & $0.05 \pm 0.01$ & $0.003 \pm 0.00$ \\
\hline & Average & & $1.54 \pm 0.01$ & $0.44 \pm 0.01$ & $1.75 \pm 0.01$ & $2.47 \pm 0.01$ & $0.17 \pm 0.01$ & $0.005 \pm 0.00$ \\
\hline & Red wines & & & & & & & \\
\hline $\mathrm{R} 1$ & Vranec 1 & 2012 & $1.89 \pm 0.01$ & $0.06 \pm 0.01$ & $0.97 \pm 0.01$ & $0.23 \pm 0.00$ & $0.11 \pm 0.01$ & $0.015 \pm 0.00$ \\
\hline $\mathrm{R} 2$ & Vranec 2 & 2011 & $1.81 \pm 0.01$ & n.d & $0.64 \pm 0.00$ & $0.12 \pm 0.01$ & $0.17 \pm 0.01$ & $0.026 \pm 0.00$ \\
\hline R3 & Merlot 1 & 2011 & $1.45 \pm 0.00$ & n.d & $0.95 \pm 0.00$ & $0.02 \pm 0.00$ & $0.42 \pm 0.01$ & $0.010 \pm 0.00$ \\
\hline $\mathrm{R} 4$ & $\begin{array}{l}\text { Cabernet } \\
\text { Sauvignon }\end{array}$ & 2012 & $2.26 \pm 0.01$ & $0.06 \pm 0.00$ & $0.49 \pm 0.01$ & $0.13 \pm 0.00$ & $0.34 \pm 0.01$ & $0.011 \pm 0.00$ \\
\hline R5 & Vranec 3 & 2012 & $2.05 \pm 0.01$ & $0.06 \pm 0.01$ & $0.48 \pm 0.01$ & $0.12 \pm 0.01$ & $0.33 \pm 0.00$ & $0.012 \pm 0.00$ \\
\hline R6 & Merlot 2 & 2012 & $1.95 \pm 0.00$ & $0.06 \pm 0.00$ & $0.46 \pm 0.01$ & $0.10 \pm 0.01$ & $0.36 \pm 0.01$ & $0.011 \pm 0.00$ \\
\hline R7 & Vranec 4 & 2012 & $1.27 \pm 0.01$ & $0.88 \pm 0.00$ & $0.12 \pm 0.01$ & $0.08 \pm 0.01$ & $0.51 \pm 0.01$ & $0.009 \pm 0.00$ \\
\hline $\mathrm{R} 8$ & Vranec 5 & 2013 & $1.47 \pm 0.01$ & $0.03 \pm 0.01$ & $0.38 \pm 0.01$ & $0.06 \pm 0.00$ & $0.21 \pm 0.01$ & $0.011 \pm 0.00$ \\
\hline R9 & Vranec 6 & 2013 & $1.74 \pm 0.01$ & $0.20 \pm 0.00$ & $0.28 \pm 0.01$ & $0.11 \pm 0.01$ & $0.50 \pm 0.01$ & $0.009 \pm 0.00$ \\
\hline \multirow[t]{2}{*}{$\mathrm{R} 10$} & Merlot 3 & 2013 & $1.56 \pm 0.00$ & $0.06 \pm 0.00$ & $0.34 \pm 0.01$ & $0.08 \pm 0.01$ & $0.37 \pm 0.01$ & $0.009 \pm 0.00$ \\
\hline & Average & & $1.75 \pm \pm 0.01$ & $0.16 \pm 0.00$ & $0.51 \pm 0.01$ & $0.11 \pm 0.01$ & $0.33 \pm 0.01$ & $0.013 \pm 0.00$ \\
\hline
\end{tabular}

In general, the analyzed wines contained organic acids in amounts that are mostly related to the varieties, but also to some extent to the applied vinification procedures. Furthermore, the acid contents were high enough to ensure an appropriate acidity of wines, which is necessary for their chemical and microbiological stability, and especially important for the sensorial characteristics and aging of wines. The obtained results for the organic acids in Macedonian wines were similar to those of previous studies published for Slovenian and Greek white and red wines [5, 8, 14], as well as for Port wines [15] and Brazilian wines [16].

\subsection{Principal component analysis}

Principal component analysis was used to study the contribution of each parameter (organic acid content) on the clustering among the wines. Projection of the wines on the first two principal components (explained variability of $72.20 \%$ ) showed separation mainly according to the wine type, red wines vs. white wines (Fig. 4a). Thus, white wines, mainly located in the positive part of PC1 $(52.03 \%)$ (except W4 and W5), were clearly separated from the red wines, located in the negative part of PC1 (except wine R7). The contribution of the variables used for characterization of the wine samples in the first two principal components is presented in Figure $4 \mathrm{~b}$. It can be noticed that malic and citric acids are located in the positive part of the first principal component, while other acids (tartaric, lactic, shikimic and succinic) prevail in the negative part of PC1. In fact, separation of the wines was performed mainly according to the content of malic and citric acids, which were present in higher amounts in white wines as malolactic fermentation was not completely performed there. Conversely, red wines presented higher contents of tartaric acid, responsible for the separation of red wines. 


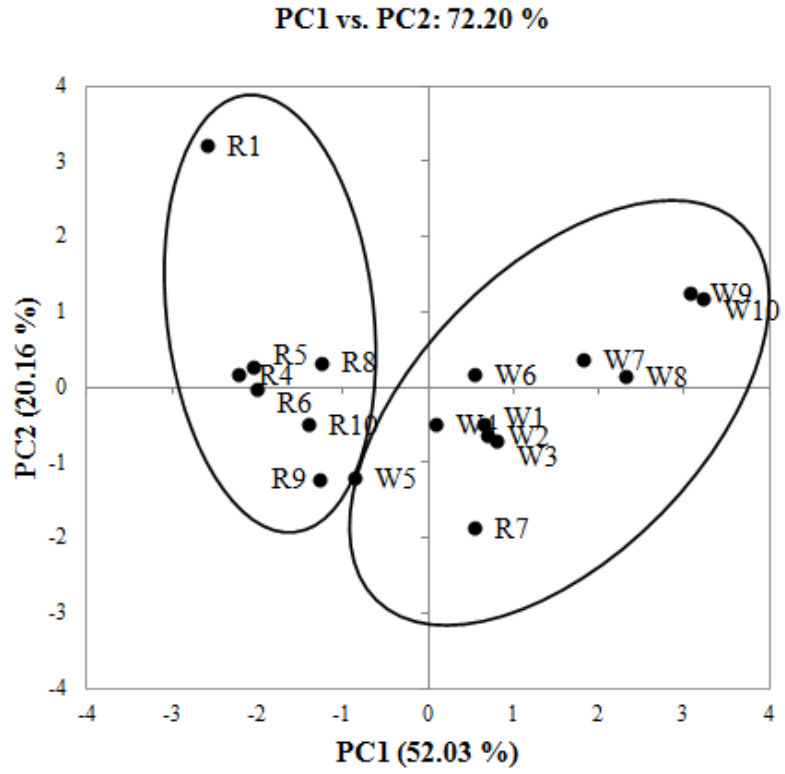

(a)

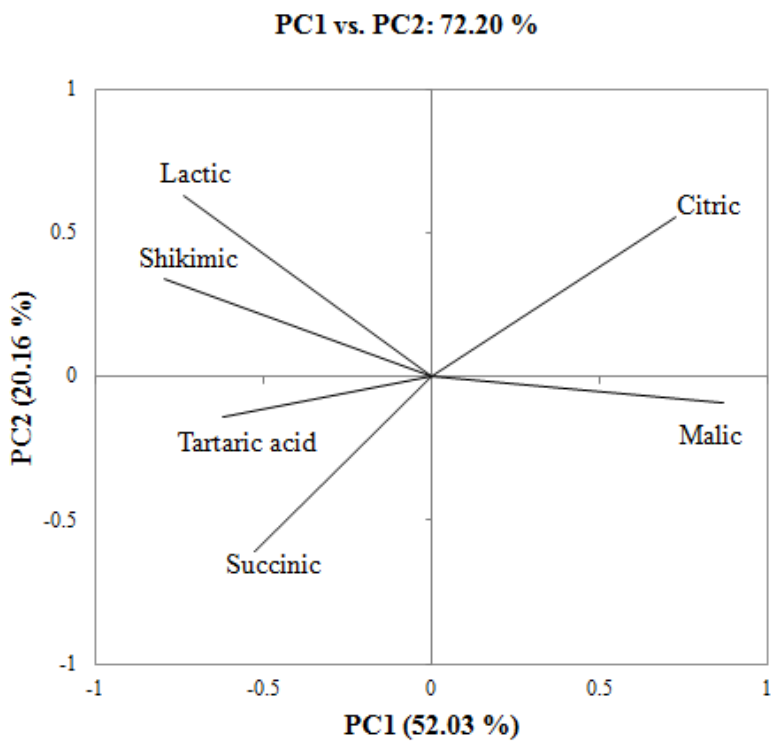

(b)

Fig. 4. Principal component score plot (a) and correlation scatterplots (b) of the variables with PC1 and PC2 based on the organic acids determined by HPLC for various white and red wines.

\section{CONCLUSIONS}

The established HPLC method presented good separation and enabled appropriate determination of the main organic acids in wine in a relatively short analysis time (less than $10 \mathrm{~min}$ ). The best separation of organic acids was achieved with Supelco LiChrosorb RP-18 column, presenting satisfactory resolution between malic and shikimic acid, that were closely eluting or co-eluting when other HPLC columns were used. The wine pretreatment involved a simple SPE method, which allowed for the successful elimination of the matrix components, resulting with good recoveries for all analytes. Good linearity, sensitivity, precision and accuracy of the method confirmed its suitability for analysis of organic acids in red and white wines. The optimized and validated method was applied on determination of organic acids in Macedonian wines, observing differences in the content that can be attributed mainly to varietal characteristics and also to vinification practices.

Acknowledgment. This research is based upon work supported by the Ministry of Education and Science of the Republic of Macedonia under the bilateral project titled: "Biogenic aminies and aroma in Vranec wines from Macedonia and Montenegro and effect of malolactic fermentation on their formation", which is gratefully acknowledged.

\section{REFERENCES}

[1] J. H. Swiegers, P. J. Chambers, I. S. Pretorius, Olfaction and taste: Human perception, physiology and genetics. Australian Journal of Grape and Wine Research, 11, 109-113 (2005).

[2] P. Ribrereau-Gayon, Y. Glories, A. Maujean, D. Dubourdieu, Handbook of Enology, The Chemistry of Wine and Stabilization and Treatments, Volume 2. John Wiley \& Sons, Ltd. (2006).

[3] T. Henick-Kling, Control of malolactic fermentations in wine: energetics, flavor modification and methods of starter culture preparation. Journal of Applied Bacteriology, 79, 29-37 (1995).

[4] C. Tessini, C. Mardones, L. Rivas, D. von Baer, Measurement uncertainty of shikimic acid in red wines produced in Chile. Accreditation and Quality Assurance, 14, 381-387 (2009).

[5] C. Mardones, A. Hitschfeld, A Contreras, K. Lepe, L. Gutiérrez, D. von Baer, Comparison of shikimic acid determination by capillary zone electrophoresis with direct and indirect detection with liquid chromatography for varietal differentiation of red wines. Journal of Chromatography A, 285-292 (2005).

[6] A. Schneider, V. Gerbi, M. Redoglia, A Rapid HPLC Method for Separation and Determination of Major Organic Acids in Grape Musts and Wines. American Journal of Enology and Viticulture, 38, 151-155 (1987).

[7] D. Tusseau, C. Benoit, Routine high-performance liquid chromatographic determination of carboxylic acids in wines and Champagne. Journal of Chromatography, 395, 323-333 (1987).

[8] E. Falque-Lopez, E. Fernández-Gómez, Simultaneous determination of the major organic acids, sugars, glycerol, and ethanol by HPLC in grape musts and white wines. Journal of Chromatographic Science, 35, 254257 (1996). 
[9] M. Kordiš-Krpež, V. Abram, M. Kač, S. Ferjančič, Determination of Organic Acids in White Wines by RPHPLC. Food Technology and Biotechnology, 39, 93-99 (2001).

[10] I. Mato, S. Suarez-Luque, J. Huidobro, Review of the analytical methods to determine organic acid in grape juices and wines. Food Research International, 38, 1175-1188 (2005).

[11] A. Hakan Aktas, S. Sen, M. Yilmazer, E. Cubuk, Determination of Carboxylic Acids in Apple Juice by RP HPLC, Iranian Journal of Chemistry and Chemical Engineering, 24, 1-6 (2005).

[12] C. R. Davis, D. Wibowo, G. H. Fleet, T. H. Lee, Properties of wine lactic acid bacteria: their potential oenological significance. American Journal of Enology and Viticulture, 39, 137-142 (1988).
[13] Official Gazette of Republic of Macedonia, No. 50, 2010.

[14] A. Zotu, Z. Lokou, O. Karava, Method Development for the Determination of Seven Organic Acids in Wines by Reversed-Phase High Performance Liquid Chromatography. Chromatographia, 60, 39-44 (2004).

[15] V. I. Esteves, S. S. F. Lima, D. L. D. Lima, A. C. Duarte, Using capillary electrophoresis for the determinationof organic acids in Port wine. Analytica Chimica Acta, 513, 163-167 (2004).

[16] R. G. Peres, E. P. Moraes, G. A. Micke, F. G. Tonin, M. F. M. Tavares, D. B. Rodriguez-Amaya, Rapid method for the determination of organic acids in wine by capillary electrophoresis with indirect UV detection, Food Control, 20, 548-552 (2009). 
